\title{
BURNOS HIGIENISTO VEIKLA: LIETUVOS IR SUOMIJOS ATVEJIS
}

\author{
Asta Varaškevičienė, Ernesta Urbutytė \\ Kauno kolegijos Medicinos fakultetas
}

Raktažodis: burnos higienisto veikla.

\begin{abstract}
Santrauka
Straipsnyje pristatomo tyrimo tikslas - atskleisti burnos higienistu darbo ypatumus skirtingose šalyse - Lietuvoje ir Suomijoje. Tyrime dalyvavo 424 burnos higienistai (191 iš Lietuvos, 233 iš Suomijos), dirbantys pagal šią kvalifikaciją. Taikytas duomenų rinkimo metodas - apklausa raštu. Atlikto tyrimo rezultatai parodè, kad Lietuvos ir Suomijos burnos higienistų veikloje yra ir skirtumų, ir panašumų. Didžioji dalis tyrime dalyvavusių Lietuvos burnos higienistų dirba privačiose įstaigose, pacientų apžiūrai skiria 5 - 10 min.(71\%), pacientų asmeninès higienos mokymui skiria 5 - 10 min. (55\%); didžioji dalis Suomijos burnos higienistų dirba valstybinèse įstaigose, pacientu apžiūrai skiria daugiau nei 10 min.(70\%). Ultragarsinius skalerius šalinti mineralizuotus apnašus naudoja didžioji dalis abiejų šalių burnos higienistų. Poliravimo pastą šepetėliu ar kalpokèliu po instrumentavimo naudoja beveik visi tyrime dalyvavę respondentai. Skirtingi tyrimo rezultatai stebimi naudojant sodapūtę: niekada sodapūtès nenaudoja 34 procentai Suomijos burnos higienistų, o 33 procentai Lietuvos burnos higienistų naudoja dažnai. Tyrimo rezultatai atskleidè skirtingas rekomendacijas: Lietuvos burnos higienistai rekomenduoja pacientam rankinị šepetėlị (81\%), Suomijos burnos higienistai rekomenduoja elektrinị dantų šepetèli (98\%), nerekomenduoja burnos skalavimo skysčių, visada rekomenduoja ksilitolio turinčius produktus. Abiejų šalių burnos higienistai dalyvauja edukacinèje veikloje.
\end{abstract}

\section{Ivadas}

Žymiausia pasaulio organizacija ADA (American Dental Association) vienijanti odontologus, pastaraisiais metais dažnai akcentuoja visapusiškos burnos priežiūros svarbą [1]. Bloga burnos higiena yra pagrindinis rizikos veiksnys, lemiantis burnos audinių patologiją. Apydančio ligu profilaktikai būtina individuali ir profesionali burnos higiena. Todèl vis svarbesnis vaidmuo tenka burnos higienistui. Burnos higienisto darbo sritis - odontologinių ligų rizikos faktorių išaiškinimas ir profilaktika, siekiant sumažinti dantu èduonies (karieso) ir periodonto ligu paplitimą ir intensyvumą tarp ịvairiu amžiaus grupių pacientų [10].

Daugelyje ekonomiškai išsivysčiusių Vakarų Europos šalių (Danijoje, Olandijoje, Švedijoje, Suomijoje, Norvegijoje) èduonies intensyvumas tarp dvylikamečių vaikų yra žemas ir labai žemas: Danijoje - 0,9, Olandijoje - 0,9, Švedijoje - 1,1, Suomijoje - 1,2 [4], Lietuvoje - 2,35 [12].

Lietuvoje gerą burnos higieną turinčių asmenų procentas svyruoja nuo 15 iki 30 proc. [8], o Lietuvos vaikų ir paauglių burnos higienos būklę, palyginus su kitomis Europos šalimis, galima vertinti tik patenkinamai[4].

Požiūris ị burnos ligų atsiradimą sąlygojančius veiksnius laikui bėgant kito. Iki $1960 \mathrm{~m}$. buvo teigiama, jog pagrindinis veiksnys, lemiantis periodonto ligų atsiradimą, yra mineralizuotas apnašas, dirginantis audinius, todèl pagrindinè profilaktikos priemonè - profesionali burnos higiena kas 6 mènesius ir asmenine 3 kartus dienoje. Nuo 1965 m. iki 1985 m. laikytasi teorijos, jog apydančio ligas sukelia dantų apnašas [11]. Šiuolaikiškas požiūris paremtas prielaida, kad ligos išsivystymas priklauso, kaip pacientas geba kontroliuoti patogeninę mikroflorą. Vienas iš būdų, padedančių sumažinti patogeninę mikroflorą, dažnesni vizitai pas burnos higienistą ir profesionalios burnos higienos procedūros, ypač jei asmuo ne itin efektyviai atlieka individualią burnos higieną [2]. Po $2006 \mathrm{~m}$. Suomijoje 3 metus vykusio profilaktikos projekto, ivertinus tyrimo rezultatus, nustatyta, kad Streptococus Mutans kiekis tyrime dalyvavusių vaikų burnoje sumažejo. Todèl padaryta išvada, jog individualiosios burnos higienos mokymas turi klinikinès naudos [3]. Kito tyrimo, kuris buvo atliktas Suomijos mieste Laukaa duomenimis, reguliarus ksilitolio gumos ir pastilių vartojimas sumažino dantų èduonies atsiradimą apie 50 proc. [7]. Periodonto ligos visame pasaulyje diagnozuojamos kasdien. Europos tyrimuose nurodoma, kad mažiausiai pacientu, turinčių bent vieną $\geq 4 \mathrm{~mm}$ gylio periodonto kišenę, yra Švedijoje ir Ispanijoje, daugiausiai - Lietuvoje (1997-1998 m. Regioninio tyrimo duomenimis, 95 proc.) ir Vokietijoje (88 proc.) [9]. Apibendrinant ankstesniuo- 
sius ir dabartinius mokslinius tyrimus straipsnyje norime atskleisti skirtingu šalių burnos priežiūros specialistų veiklos ypatumus, iškeliant problemini klausimą - kuo skiriasi ir kaip panaši burnos higienisto veikla Lietuvoje ir Suomijoje ? Tyrimo objektas - burnos higienisto veikla.

Tyrimo tikslas - parodyti Lietuvos ir Suomijos burnos higienistų veiklą.

\section{Tyrimo medžiaga ir metodika}

Lietuvoje burnos higienisto veiklą reglamentuoja Lietuvos medicinos norma MN 35: 2012 „Burnos higienistas. Teisès, pareigos, kompetencija ir atsakomybéc. Lietuvoje burnos higienistus ruošiančios mokymo institucijos yra įsikūrusios Kaune, Klaipedoje, Šiauliuose, Panevėžyje, Utenoje. Užsienyje igyta burnos higienisto profesinè kvalifikacija pripažistama Lietuvos Respublikos teisès aktų nustatyta tvarka [10]. Suomijoje burnos higienisto veikla reglamentuojama istatymu sveikatos priežiūros specialistams (559/1994, $1030 / 2000)$ ir sveikatos priežiūros specialistu reglamentu (564/1994, 824/1999). Mokymo institucijos, kuriose rengiami burnos priežiūros specialistai - burnos higienistai, ịsikūrusios Suomijos sostineje Helsinkyje ir dar trijuose Suomijos miestuose (Turku, Oulu, Kuopio)[8]. Tarptautinès burnos higienistų federacijos (IFDH) duomenimis, ne Europos Sajungos šalyse igiję burnos higienisto kvalifikaciją asmenys, norėdami dirbti Suomijoje burnos higienisto darbą, privalo išlaikyti šalies valstybini egzaminą [10].

Taigi, burnos higienistas yra savarankiškai dirbantis burnos priežiūros specialistas, kurio kompetencija apima ne tik profesionalios burnos higienos paslaugų teikimą, bet ir profilaktinių programų igyvendinimą, dalyvavimą moksliniuose tyrimuose ir projektuose [2].

Burnos higienisto kompetencija Lietuvoje ir Suomijoje apima burnos sveikatos palaikymą ir profilaktiką. 1 lentelèje išskiriami Lietuvos ir Suo-
1 lentelè. Lietuvos ir Suomijos burnos higienistų kompetencijos

\begin{tabular}{|c|c|}
\hline $\begin{array}{l}\text { Lietuvos burnos higienisto kompetencijos } \\
\text { Lietuvos medicinos norma MN } 35: 2012 \text {, } \\
\text { VII. Kompetencija }\end{array}$ & $\begin{array}{l}\text { Suomijos burnos higienisto kompetencijos } \\
\text { Tarptautiné burnos higienistų federacija (IFDH, } \\
\text { 2014) }\end{array}$ \\
\hline $\begin{array}{l}\text { 1. Dantų vageles hermetizuoti silantais } \\
\text { 2. Atlikti dantų balinimo procedūras } \\
\text { 3. Paskyrus gydytojui odontologui, gydy- } \\
\text { tojui odontologui specialistui, atlikti dantų } \\
\text { rentgenogramas } \\
\text { 4. Išmatuoti dantenų ir periodonto kišenes } \\
\text { 5.Parinkti ir pritaikyti instrumentus profe- } \\
\text { sionaliai burnos higienai } \\
\text { 6. Pašalinti viršdanteninius ir podanteninius } \\
\text { konkrementus } \\
\text { 7. Poliruoti dantis } \\
\text { 8. Atlikti vietinį nuskausminimą (aplikacinį, } \\
\text { infiltracini ) } \\
\text { 9. Atlikti burnos irigacijas } \\
\text { 10. Taikyti vietines dantu èduonies profilak- } \\
\text { tikos priemones (skalavimą fluoro tirpalais, } \\
\text { fluoro laką, želè ir kt.) } \\
\text { 11. Atlikti injekcijas po oda, ị raumenis } \\
\text { 12. Teikti būtinają medicinos pagalbą teisès } \\
\text { aktų nustatyta tvarka } \\
\text { 13.Suteikti būtinają medicinos pagalbą } \\
\text { pacientui apsinuodijus fluoru [2]. }\end{array}$ & $\begin{array}{l}\text { 1. Individualiosios burnos higienos mokymas, } \\
\text { 2. Pirminis burnos ligų diagnozavimas } \\
\text { 3. Burnos sveikatos palaikymas ir profilaktika } \\
\text { 4. Ortodontinius aparatus nešiojančių pacientų } \\
\text { burnos ertmės priežiūra } \\
\text { 5. Pacientų, kurie yra prieš/po veido ir } \\
\text { žandikaulių ar periodontologinių operacijų } \\
\text { burnos ertmės priežiūra } \\
\text { 6. Pacientų nešiojančių dantų protezus burnos } \\
\text { ertmės priežiūra } \\
\text { 7. Rentgeno nuotraukų atlikimas } \\
\text { 8. Vietinis nuskausminimas } \\
\text { 9. Sveikatos programų taikymas ir tobulinimas } \\
\text { visose pacientų amžiaus grupėse } \\
\text { 10. Viršdanteninių ir podanteninių } \\
\text { konkrementų šalinimas (rankiniais instrumen- } \\
\text { tais ir ultragarsiniu skaleriu) } \\
\text { 11. Dantų poliravimas [10]. }\end{array}$ \\
\hline
\end{tabular}

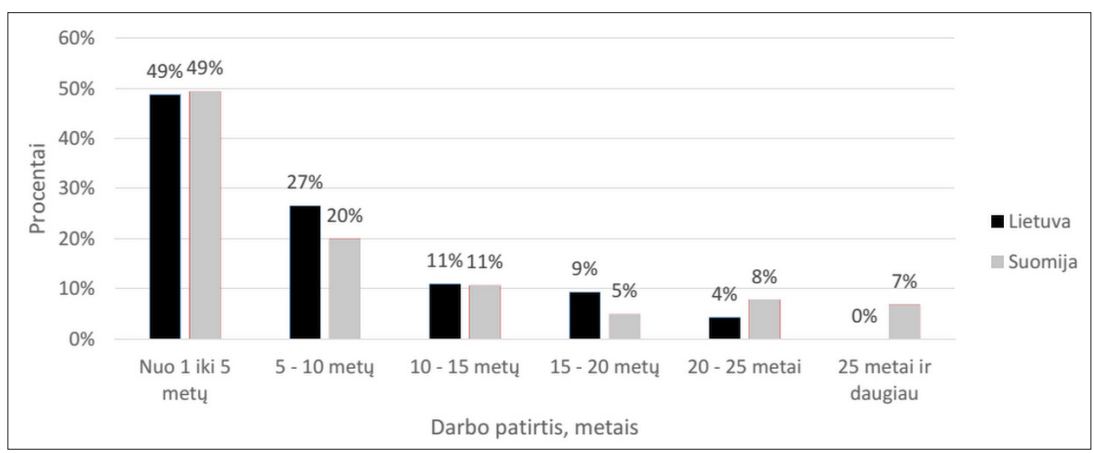

1 pav. Lietuvos ir Suomijos respondentų pasiskirstymas pagal darbo patirtị (Lietuva N=191; Suomija N=233)

mijos burnos higienisto gebejimai. Todèl abiejose šalyse, siekiant sumažinti burnos ligų paplitimą ir intensyvumą bei stiprinti burnos sveikatą populiacijoje, diegiamos profilaktinès programos, vykdomi ịvairūs projektai. Visavertis bendradarbiavimas tarp programos vykdytojų padeda pasiekti ne tik gerų burnos sveikatos rezultatų, bet ir pagerinti bendrają sveikatos būklę [13].

Išanalizavus Lietuvos ir Suomijos burnos higienistų kompetencijas, kurios nustatytos teisiniais aktais galime teigti, kad esminių skirtumų nèra.

Tyrimo organizavimas, imties sudarymo principai. Tyrimas vyko 2015 m. balandžio - gegužès mèn. Didžiųjų Lietuvos miestų odontologijos klinikoms ir odontologijos kabinetams išsiųsta 60 elektroniniu laišku su internetine anketos (www.manoapklausa.lt) nuoroda prašant dalyvauti tyrime. Taip pat internetine anketos nuoroda su kvietimu dalyvauti apklausoje publikuota Lietuvos burnos higienistų draugijos internetinèje svetainèje. Suomijoje internetiné anketos nuoroda publikuota viešosiose internetinèse burnos higienistų grupése ir Suomijos burnos higienistų draugijos internetineje svetainejje. Internetu buvo užpildytos 424 anketos. Anketos nustatymuose buvo nurodyta, jog neatsakius 


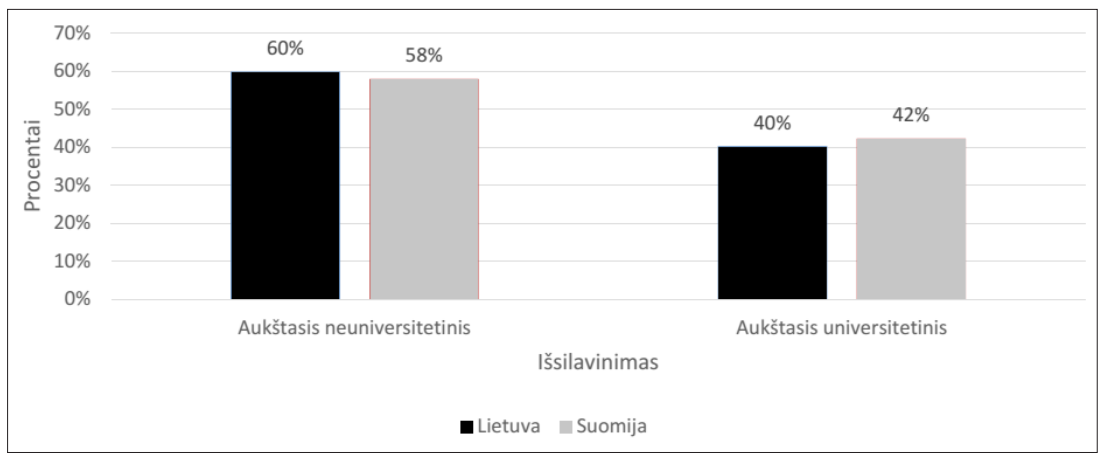

2 pav. Lietuvos ir Suomijos respondentų pasiskirstymas pagal išsilavinimą (Lietuva N=191; Suomija N=233)

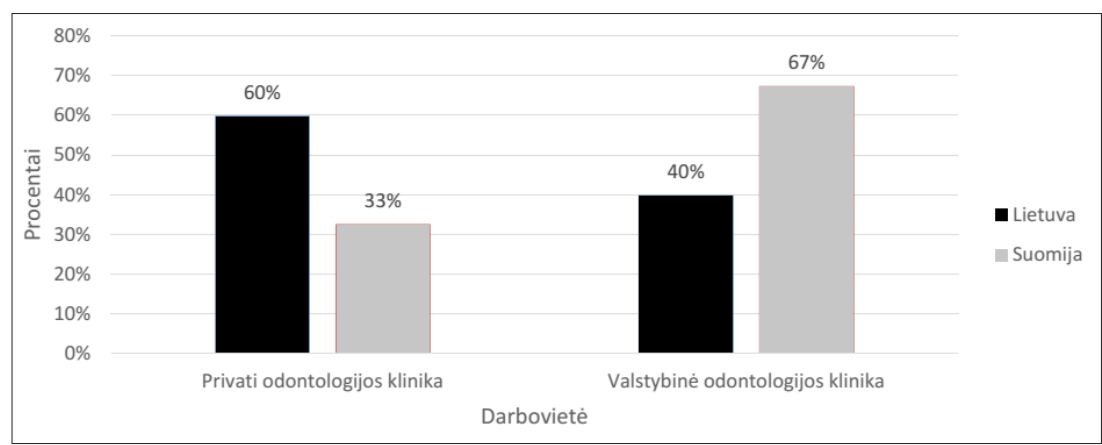

3 pav. Lietuvos ir Suomijos respondentų pasiskirstymas pagal darbovietę (Lietuva N=191; Suomija N=233)

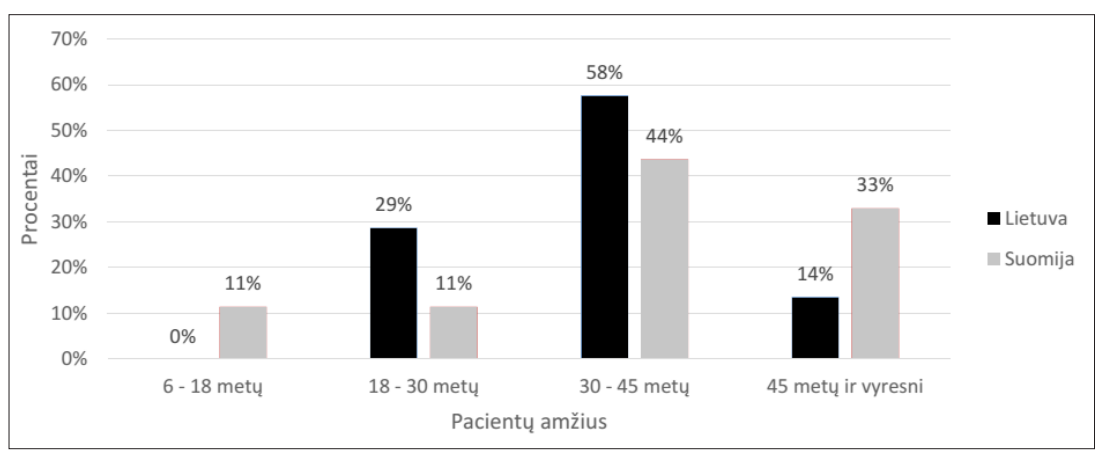

4 pav. Lietuvos ir Suomijos respondentų pasiskirstymas pagal pacientų amžių, su kuriuo jie dažniausiai susidūria savo darbe (Lietuva $\mathrm{N}=191$; Suomija $\mathrm{N}=233$ )

ị bent vieną klausimą, anketos patvirtinti negalima, todèl ne visiškai užpildytų anketų nebuvo. Tyrimo imties nustatymui naudota V.I. Paniotto formulè. Lietuvoje licenciją dirbti turi 802 burnos higienistai [14], Suomijoje - 2200 [6].

Tyrimo metu naudotas duomenų rinkimo metodas - apklausa raštu, tyrimo instrumentas - anketa. Anketą sudare 18 klausimų. Tyrime dalyvavo 424 burnos higienisto išsilavinimą turintys asmenys, iš kurių 191 Lietuvos ir 233 Suomijos. Respondentų darbo patirtis nuo 1 iki 25 metų (1 paveikslas).

Kaip matome antrajame paveiksle, didžioji dalis tyrime dalyvavusių bur- nos higienistų yra ịgiję aukštaji neuniversitetinị išsilavinimą (2 paveikslas).

Didžioji tyrime dalyvavusiu Lietuvos burnos higienistų dalis $(60 \%)$ dirba privačiame sektoriuje, Suomijos $(67 \%)$ burnos higienistu - valstybiniame (3 paveikslas).

\section{Tyrimo rezultatai}

Tyrimo rezultatai atskleidè, kad dažniausiai abiejų šalių burnos higienistai savo darbe susiduria su $30-45$ metų pacientais (Lietuvoje - 58 proc., Suomijoje - 44 proc.). Ryškus skirtumas pastebimas analizuojant $6-18$ metu pacientų amžiaus grupę. Tyrime dalyvavusių Lietuvos burnos higienistų darbe šios amžiaus grupés nebuvo, Suomijos - net 11 proc. Didesnis skaičius $6-18$ metų pacientų Suomijoje gali būti dèl to, kad jų veikla nukreipta ị valstybinị sektorių, kuriame vaikų iki 18 metu gydymas nemokamas (4 paveikslas).

Kaip matyti penktame paveiksle, dauguma (71\%) Lietuvos burnos higienistų pacientų apžiūrai skiria apytiksliai 5 - 10 minučių, o Suomijos 10 ir daugiau minučių (apytiksliai 51\%) (5 paveikslas).

Atlikto tyrimo rezultatai atskleide, kad Lietuvos ir Suomijos burnos higienistų instrumento pasirinkimas mineralizuoto apnašo šalinimui skiriasi gana nežymiai.89 procentai Lietuvos respondentų ir 77 procentai Suomijos renkasi ultragarsini skalerị (6 paveikslas).

Didžioji dalis abiejų šalių burnos higienistų (93 proc. Lietuvos respondentų, 97 proc. Suomijos respondentų) atsakè, kad po instrumentavimo atlieka dantu poliravimą pasta ir šepetėliu ar guminiu kalpokèliu . Nemaža dalis (93 proc. Lietuvos respondentų, 97 proc. Suomijos respondentų) po instrumentavimo tarpdančius valo abrazyvinèmis juostelèmis. Tačiau pastebima, jog didesnè Lietuvos apklausos dalyvių dalis (55 proc.) po instrumentavimo dantis poliruoja oro abrazijos būdu, o Suomijos tik nedidelè dalis (8 proc.) (7paveikslas ).

8 paveiksle matyti, kad 33 procentai Lietuvoje dirbančiu burnos higienistu pigmentinio ir minkštojo apnašo šalini- 
mui labai dažnai naudoja sodapūtę, 18 procentų visada , 34 procentai Suomijos tyrime dalyvavusiu burnos higienistų sodapūtès nenaudoja niekada, o 30 procentų - kartais (8 paveikslas).

Analizuojant tyrimo dalyvių laiką, skiriamą paciento asmeninès burnos higienos mokymui, stebime panašius rezultatus: 55 proc. Lietuvos ir 57 proc. Suomijos burnos higienistų skiria 5-10 minučių (9 paveikslas).

Analizuojant Lietuvos ir Suomijos respondentų rekomenduojamus dantų šepetèlius stebime skirtumus: 98\% Suomijos burnos higienistų rekomenduoja elektrini, o $81 \%$ Lietuvos burnos higienistu rankini (10 paveikslas).

Kaip matome antroje lentelèje, dauguma Lietuvos (62 proc.) ir Suomijos (97 proc.) burnos higienistu ksilitolio turinčius produktus vertina teigiamai, tačiau Lietuvos burnos higienistai jų neskiria, Suomijos burnos higienistai rekomenduoja visada.

\section{Išvados}

1. Burnos higienistai tiek Lietuvoje, tiek Suomijoje yra savarankiškai dirbantys burnos priežiūros specialistai, savo veiklą atlieka remdamiesi teisiniais reglamentais. Burnos higienisto veiklą apima profesionalios burnos higienos paslaugų teikimas, profilaktinių programu igyvendinimas, dalyvavimas moksliniuose tyrimuose ir projektuose. Burnos higienistų veikla yra nukreipta ị burnos sveikatos skatinimą ir palaikymą vykdant burnos ligu profilaktiką.

2. Tyrimo rezultatai atskleide, kad didžioji dalis Lietuvos burnos higienistų dirba privačiame, o Suomijos - valstybiniame sektoriuje. Suomijos burnos higienistai turi daugiau pacientų iki $18 \mathrm{~m}$. amžiaus, apžiūrai skiria daugiau laiko. Lietuvos burnos higienistai sodapūtę naudoja dažnai, Suomijos - nenaudoja. Suomijos burnos higienistai mano, kad elektrinį dantų šepetèlị naudoti tikslingiau, Lietuvos - rekomenduoja rankinį. Ksilitolio turinčius produktus Suomijos burnos higienistai rekomenduoja kiekvienam, Lietuvos - nerekomenduoja.

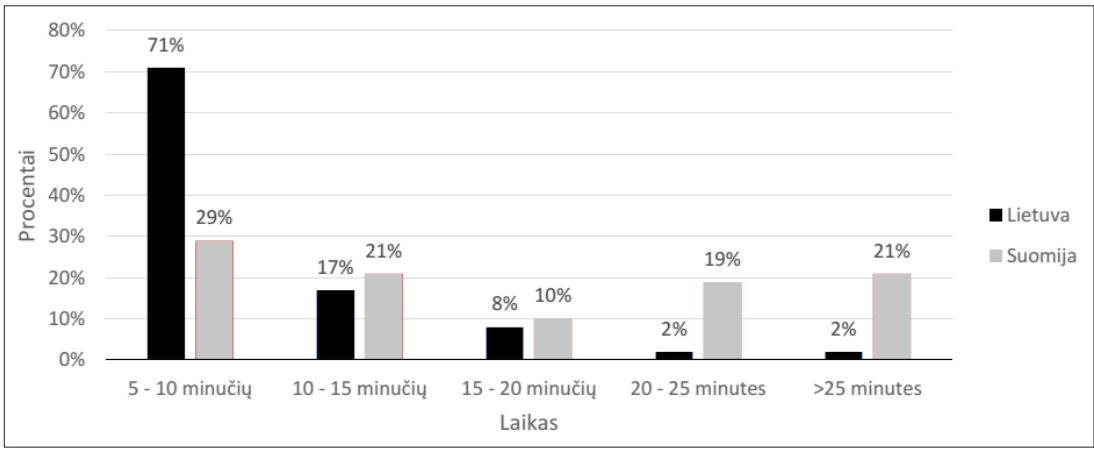

5 pav. Lietuvos ir Suomijos respondentų pasiskirstymas pagal paciento apžiūrai skiriamą laiką (Lietuva N=191; Suomija $\mathrm{N}=233$ )

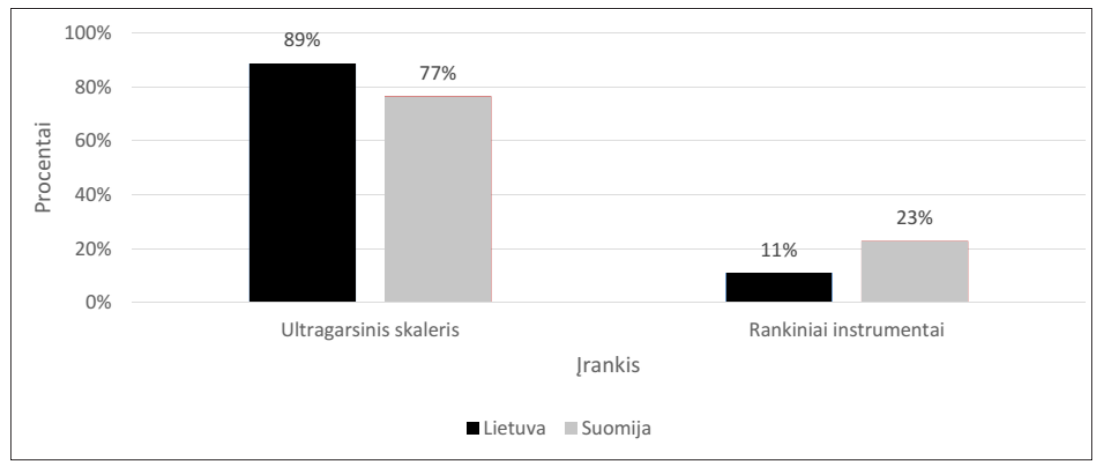

6 pav. Lietuvos ir Suomijos respondentų pasiskirstymas pagal mineralizuoto apnašo šalinimui naudojamus įrankius (Lietuva $\mathrm{N}=191$; Suomija $\mathrm{N}=233$ )

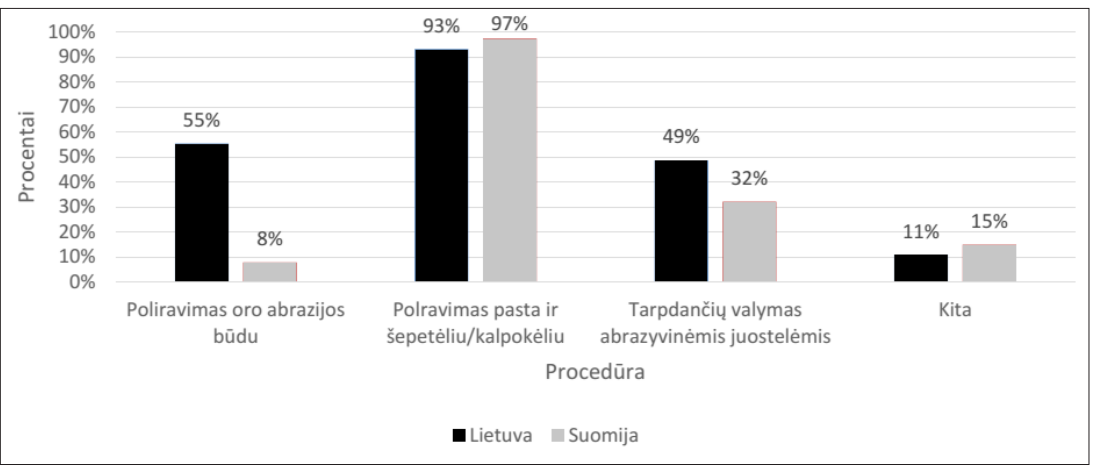

7 pav. Lietuvos ir Suomijos respondentų pasiskirstymas pagal procedūras, atliekamas po instrumentavimo (Lietuva N=191; Suomija $\mathrm{N}=233$ )

\section{Literatūra}

1. ADA affirms benefits of ADA-Accepted antimicrobial mouth rinses and toothpastes, fluoride mouth rinses. Chicago, IL: American Dental Association; May 23, 2007 [žiūrèta 2015-04-09] Prieiga per internetą: $<$ http://ada.org/pubhttp://ada.org/public/ media/releases/0705_release03.asp.

2. 2.Andruškienė J. Burnos ligų epidemiologija ir profilaktika, Klaipėda: Klaipėdos 


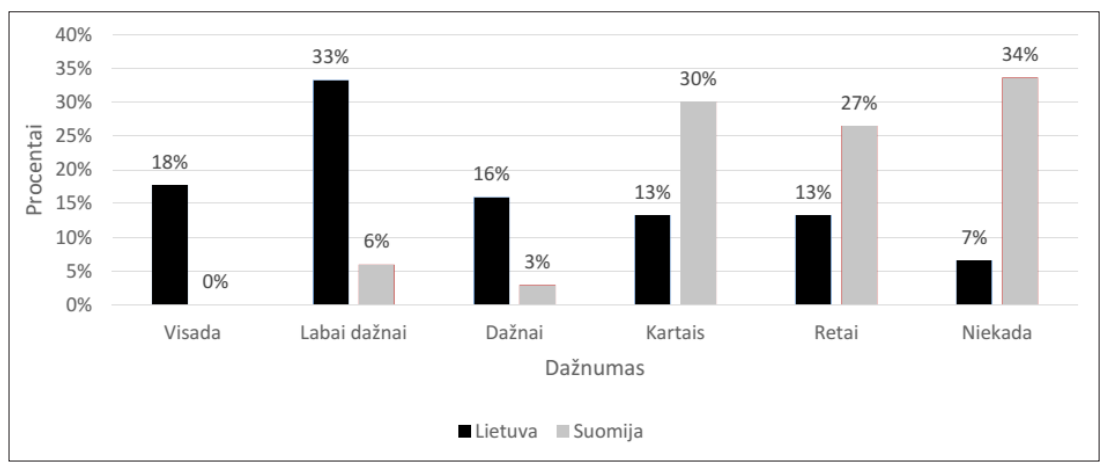

8 pav. Lietuvos ir Suomijos respondentų pasiskirstymas pagal sodapūtès naudojimo dažnumą (Lietuva N=191; Suomija N=233)

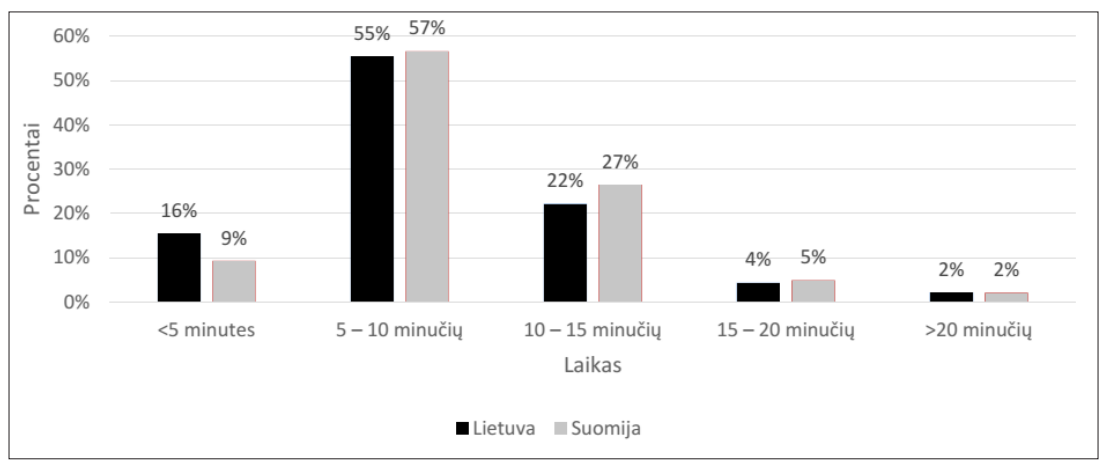

9 pav. Lietuvos ir Suomijos respondentų pasiskirstymas pagal laiką, skiriamą paciento asmeninès burnos higienos mokymui (Lietuva N=191, Suomija N=233)

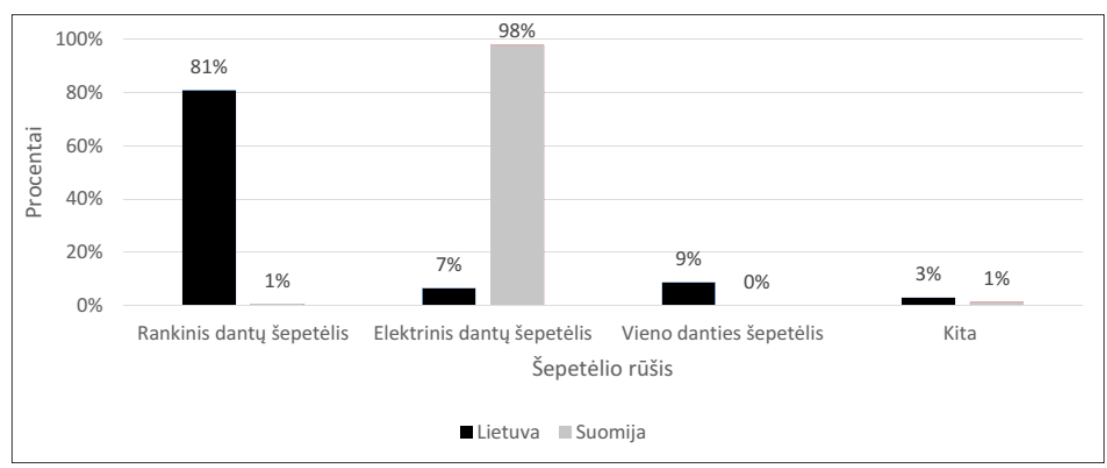

10 pav. Lietuvos ir Suomijos respondentų dažniausiai rekomenduojami dantų šepetėliai (Lietuva N=191; Suomija N=233)

universiteto leidykla, 2012; 5-90.

3. Arpalahti I, Tolvanen M, Pienihakkinen K. Comparing Health Promotion Programs in Public Dental Service of Vantaa, Finland: A Clinical Trial in 6-36-Month-Old Children// International Journal of Dentistry 2013; 9. Article ID 757938. [žiūrèta 2015-04-11] Prieiga per internetą: <http://dx.doi.org/10.1155/2013/757938>

4. Blinkhorn AS, Downer MC, Drugan CS. Policies for improving oral health in Europe// Health Education Journal 2005; 64(3):197-217.

http://dx.doi.org/10.1177/001789690506400302
5. Finnish Association of Dental Hygienists FADH// Koulutus, Suuhigienistikoulutus, 2015. [žiūrèta 2015-04-09] Prieiga per internetą: $<$ http://www.suuhygienistiliitto.fi/koulutus/suuhygienistikoulutus/>

6. International Federation of Dental Hygienists// Working Abroad, 2014. [žiūrèta 2015-04-09]

7. Halonen H, Pesonen P, Seppä L, Peltonen E, Tjäderhane L, Anttonen V. Outcome of a Community-Based Oral Health Promotion Project on Primary Schoolchildren's Oral Hygiene Habits// International Journal of Dentistry 2013; 6. Article ID 485741[žiūrèta 2015-0411] Prieiga per internetą: http://dx.doi. org/10.1155/2013/485741 http://dx.doi.org/10.1155/2013/485741

8. Kelbauskienè S., Paipalienė P., Kelbauskas E. Šauktinių į Lietuvos kariuomenę burnos higiena ir apydančio audinių būklè// Stomatologija, 2002; 4(2):10-13.

9. Krukonis G., Žekonienė J. Periodonto ligų paplitimo tyrimai Lietuvoje// Odontologų rūmų žinios. 2013; 3(33): 20-22.

10. Lietuvos medicinos norma MN 35:2012 Burnos higienistas. Teisès, pareigos, kompetencija ir atsakomybè"//Valstybès žinios, 2013-01-03; 1-14.

11. Löe H. The Gingival Index, the Plaque Index, and the Retention Index// Journal of Periodontology. 1965; 38: 610-616. http://dx.doi.org/10.1902/ jop.1967.38.6_part2.610

12. Milčiuvienè S., Skirbutienè S., Vasiliauskienè I. Moksleivių burnos būklès kitimas vaikų dantų profilaktikos programos metu// Stomatologija, 2000; 2(4):7-10.

13. Nathe Ch. N. Dental Public Health and Research. Third Edition. Pearspn, 2010; 7-17.

14. Valstybinè akreditavimo sveikatos priežiūros veiklai tarnyba prie SAM Prieiga per internetą: http://www.vaspvt.gov.lt/

\section{MOUTH HYGIENIST PRACTICE: LITHUANIAN AND FINLAND CASE}

A. Varaškevičienė, E. Urbutytė

Key words: oral hygienist's activity. Summary

The purpose of this article is to reveal the peculiarities of mouth hygienists work in 
different countries - Lithuania and Finland. There were 424 licensed mouth hygienists who participated in the research (191 participants from Lithuania and 233 participants from Finland). The results of the research have shown differences and similarities between mouth hygienist practices in mentioned countries. Mouth hygienists are independently working professionals who practice according to the basis of regulations both in Lithuania and Finland. The practice of mouth hygienist covers the professional service of mouth hygiene procedures, implementation of prevention programs, participation in scientific researches and projects. The practice of mouth hygienists is oriented in health promotion and support while implementing prevention programs of mouth diseases. The results of the research have shown that the major part of Lithuanian mouth hygienists work in private practice while Finnish mouth hygienists mostly work in the public sector. Finnish mouth hygienists have more patients under 18 years of age and dedicate more time for patient evaluation. Lithuanian mouth hygienists are using air polisher more often in their daily practice while Finnish specialists do not practice such methods. Finnish mouth hygienists have positive opinion on using electric tooth brush while Lithuanian specialists advice on using manual toothbrush for their patients. Finnish mouth hygienists recommend xylitol containing products for every patient while Lithuanian experts refrain from such recommendations.

Correspondence to: astavar@takas.lt

Gauta 2015-10-12
2 lentelė. Lietuvos ir Suomijos burnos higienistų nuomonè apie ksilitolio produktus

\begin{tabular}{|c|c|c|c|c|}
\hline & $\begin{array}{c}\text { Lietuvos respondentụ } \\
\text { nuomoné }\end{array}$ & Proc. & $\begin{array}{l}\text { Suomijos respondentụ } \\
\text { nuomoné }\end{array}$ & Proc. \\
\hline $\begin{array}{l}\text { NETURI } \\
\text { NUOMONESS }\end{array}$ & $\begin{array}{l}\text { Neturiu nuomonès. } \\
\text { Nenaudoju. }\end{array}$ & 36 & Neturiu nuomonès. & 3 \\
\hline $\begin{array}{l}\text { PROFILAKTINE் } \\
\text { PRIEMONÉ NUO } \\
\text { DANTŲ ĖDUONIES }\end{array}$ & $\begin{array}{l}\text { Tyrimais irodyta, kad ksili- } \\
\text { tolis yra veiksminga dantų } \\
\text { ėduonies profilaktikos prie- } \\
\text { moné, nes suardo bakteriju } \\
\text { kolonijas ant dantu paviršiaus } \\
\text { ir taip sumažina apnašų susi- } \\
\text { darymą ir skatina dantu re- } \\
\text { mineralizaciją. Tačiau, kad ir } \\
\text { kaip bebūtu gaila, Lietuvoje } \\
\text { šios produkcijos nemačiau. } \\
\text { Yra teigiama, kad ksilitolis } \\
\text { efektyvesnè priemonè nei flu- } \\
\text { oras, kuri apsaugo dantis nuo } \\
\text { ėduonies. }\end{array}$ & 25 & $\begin{array}{l}\text { Ksilitolis stabdo rūgščių poveiki } \\
\text { dantims, mažina apnašų kaupi- } \\
\text { mąsi ir lengvina jų šalinimą. No- } \\
\text { recciau, kad ksilitolio vartojimas } \\
\text { taptų viso pasaulio ípročiu. Ksi- } \\
\text { litolis yra profilaktinė priemonè } \\
\text { nuo dantų ėduonies, nes mažina } \\
\text { seilių pH. }\end{array}$ & 30 \\
\hline $\begin{array}{l}\text { CUKRAUS } \\
\text { PAKAITALAS }\end{array}$ & $\begin{array}{l}\text { Ksilitolis - puikus cukraus } \\
\text { pakaitalas, mažiau kenkia } \\
\text { dantims. Puikus saldiklis, } \\
\text { kurio nefermentuoja burnoje } \\
\text { esančios bakterijos. }\end{array}$ & 8 & - & \\
\hline $\begin{array}{l}\text { PRIEMONE் KSE- } \\
\text { ROSTOMIJOS PRO- } \\
\text { BLEMAI SPRĘSTI }\end{array}$ & $\begin{array}{l}\text { Ksilitolis - puiki priemoné, } \\
\text { padedanti spręsti burnos sau- } \\
\text { sumo problemą, nes stimu- } \\
\text { liuoja seilių išsiskyrimą. }\end{array}$ & 7 & $\begin{array}{l}\text { Ksilitolis skatina seiliu išsisky- } \\
\text { rimą, todèl rekomenduoju paci- } \\
\text { entams, kurie skundžiasi burnos } \\
\text { sausumu. }\end{array}$ & 5 \\
\hline $\begin{array}{l}\text { KSILOTOLIS } \\
\text { NAUDINGAS }\end{array}$ & $\begin{array}{l}\text { Ksilitolis naudingas, bet su } \\
\text { saiku. }\end{array}$ & 22 & $\begin{array}{l}\text { Ksilitolio produktai yra labai } \\
\text { naudinga vaikų (ypač keičiantis } \\
\text { sąkandžiams), paaugliu ir nèš- } \\
\text { čiujų (apsauga nuo dantų èduo- } \\
\text { nies, apsaugo nuo streptococcus } \\
\text { mutans perdavimo per seilių } \\
\text { kontaktą) burnos sveikatos pa- } \\
\text { laikymo dalis, tačiau neatstoja } \\
\text { dantų valymo šepetėliu ir siūlu. } \\
\text { Savo pacientams rekomenduoju } \\
\text { ksilitolio kramtomają gumą ir } \\
\text { pastiles, ypač po valgio (5 g per } \\
\text { dieną). Ksilitolis labai naudin- } \\
\text { gas dantims, nes stiprina dantų } \\
\text { emali ir apsaugo nuo ausų infek- } \\
\text { cijų. Ksilitolis naudingas visoms } \\
\text { amžiaus grupėms - vaikams, } \\
\text { suaugusiems, pagyvenusiems } \\
\text { pacientams. Ksilitolis naudingas } \\
\text { pacientams, turintiems aktyvų } \\
\text { dantų ėduonị (skatina emalio re- } \\
\text { mineralizaciją po valgio). }\end{array}$ & 62 \\
\hline JOKIOS NAUDOS & Neturi teigiamo poveikio. & 2 & - & \\
\hline
\end{tabular}

